Article

\title{
The Effect of a Fly Ash-Based Soil Conditioner on Corn and Wheat Yield and Risk Analysis of Heavy Metal Contamination
}

\author{
Yanjun Ou ${ }^{1}$, Shuhua Ma ${ }^{1, *}$, Xiao Zhou ${ }^{2}$, Xiaohui Wang ${ }^{1}$, Jianping Shi ${ }^{2}$ and Yi Zhang ${ }^{1}$ \\ 1 National Engineering Laboratory for Hydrometallurgical Cleaner Production Technology, \\ Key Laboratory of Green Process and Engineering, Institute of Process Engineering, \\ Chinese Academy of Sciences, Beijing 100190, China; ouyanjun18@mails.ucas.ac.cn (Y.O.); \\ wangxh@ipe.ac.cn (X.W.); yizh@ipe.ac.cn (Y.Z.) \\ 2 Lignite and Fly Ash Engineering Technology Research Institute, Xilingol Professional College, \\ Xilinhot 026000, China; zhouxiao199012@163.com (X.Z.); shijp07@163.com (J.S.) \\ * Correspondence: shma@ipe.ac.cn; Tel./Fax: +86-10-82545032
}

Received: 13 August 2020; Accepted: 31 August 2020; Published: 4 September 2020

\begin{abstract}
The utilization of coal fly ash (CFA) as a soil conditioner has been a research hotspot in recent years. In this paper, the continuity and stability of the yield-increasing effect of a fly ash-based soil conditioner were investigated through field trials for three consecutive years. The yield-increasing effect and applicability were also investigated by planting a variety of crops in different types of soil. Field test results revealed that the new fly ash-based soil conditioner had wide adaptability and stability under the condition of reducing the application of traditional fertilizers by $20 \%$. For corns grown in castano-cinnamon soil and dark brown soil, the application of the new fly ash-based soil conditioner for three consecutive years has steadily increased the yield by more than $10 \%$. The yield of wheat planted in castano-cinnamon soil also increased by $15 \%$. Additionally, considering that heavy metals (HMs) contained in the fly ash-based soil conditioner may cause environmental contamination, this paper calculated and analyzed the bio-concentration factor (BCF) and the translocation factor (TF) of $\mathrm{Cr}, \mathrm{As}, \mathrm{Cd}, \mathrm{Hg}$ and $\mathrm{Pb}$ in the corn experimental fields. The results showed that the five heavy metals were not significantly enriched in various parts of the corn stalk after application of the soil conditioner, and there was temporarily no environmental risk in terms of returning straws to the field or raising livestock.
\end{abstract}

Keywords: fly ash; soil conditioner; plant growth; heavy metal; risk analysis

\section{Introduction}

Coal fly ash (CFA), a solid residue produced in coal-fired power stations [1], has a high annual output as well as a negative impact on the environment in China, which has become an urgent issue to be solved. Now, its annual production is estimated to be more than 600 million tons [2]. To make matters worse, half of CFA is produced in northern China where the population density and economy development level are relatively low, so CFA cannot be completely consumed by traditional methods such as brick, cement, concrete and catalyst [3-5]. This inevitably leads to a large amount of CFA accumulation. Therefore, it is urgent to develop new methods to utilize CFA with higher efficiency and profitability.

It is acknowledged that CFA is produced by the transformation of clay minerals in coal during the process of coal combustion [6]. The main components of CFA are thereby alumina and silica, which are very similar to those of natural clay. In general, the contents of alumina and silica in CFA are about $20-40 \%$ and $40-60 \%$, respectively [7]. Additionally, CFA contains a small amount of $\mathrm{Mg}$, $\mathrm{Na}$, 
$\mathrm{P}, \mathrm{K}$, and $\mathrm{S}$, as well as trace elements such as $\mathrm{As}, \mathrm{B}, \mathrm{Mn}, \mathrm{Cu}$ and $\mathrm{Zn}$. Comparatively speaking, $\mathrm{Si}, \mathrm{Al}$, $\mathrm{Fe}$ and $\mathrm{Ca}$ are most present in CFA; Mg, Na, P, K and $\mathrm{S}$ account for $0.5 \%$ to $3.5 \%$, and trace elements account for less than $0.1 \%$. Among all the elements mentioned above, $\mathrm{P}, \mathrm{Si}, \mathrm{Ca}, \mathrm{Fe}, \mathrm{Mg}, \mathrm{K}, \mathrm{S}, \mathrm{B}, \mathrm{Zn}, \mathrm{Mn}$, $\mathrm{Cu}$, etc. are all nutrients required for plant growth [8]. The main phases of CFA are mullite, quartz and/or amorphous silica depending on the variety of raw coal and the combustion temperature of the coal-fired boiler. Moreover, there is a small amount of ferrite, anorthite, olivine, sulfate and so on in the CFA. These components are not chemically steady, so they can be transformed and absorbed by plants under specific conditions.

The porous structure of CFA makes it commonly used as a water-retaining product, and its function of loosening soil can work to improve soil structure. Moreover, CFA contains a lot of nutrients required for plant growth [8], so in recent years, the bio-concentration factor (BCF) has become a new hot issue with regards to soil conditioners. The research of Song et al. [9] showed that the application of CFA alone can effectively increase the water holding capacity of soil, and the combined application of CFA and organic matter can synergistically mitigate soil water evaporation. However, when CFA is directly applied to farmland without any processing, due to the poor activity of CFA formed by high temperature sintering, the water retention efficiency of CFA is not high enough [10], and the nutrient utilization efficiency is also low [11]. Based on its high specific surface area and alkalinity, CFA has adsorption characteristics for metals, which may have a negative effect on the absorption of certain metal elements by some plants, resulting in a decrease in the quantity of dry matter [12] (the mass remaining after plant tissue loses free water). After BCF is applied to the soil, the interaction of various ions will heighten the value of $\mathrm{pH}$ and the electrical conductivity (EC) in the soil as a whole [13]. Moreover, high-dose application of CFA may significantly increase the salinity of soil, reducing soil fertility and even resulting in toxic elements being released and groundwater pollution [14]. The process of activation and modification of fly ash can activate nutrients or improve water retention capacity, to reduce its application amount. Additionally, lots of studies have shown that the application of fly ash-based soil conditioner will not enhance the accumulation of heavy metals (HMs) in various plant tissues, and the application of fly ash-based soil conditioner in a safe ratio (less than $8 \%$ ) is beneficial to plant growth and development $[15,16]$. However, these studies are limited to laboratory research, and the risk of CFA heavy metals contamination and large-scale field trials are rarely reported.

Essentially, CFA is a by-product of the high-temperature conversion of inorganic minerals doped in coal. It comes from the process of geological changes and eventually returns to nature. This study attempts to make full use of CFA to improve soil structure and balance soil nutrients while returning it to the earth. Our research group has successfully developed a fly ash activation and modification process in the early stage [17]. This process completed the chemical activation and modification of CFA by controlling the activation temperature as well as duration and by adding a calcium-containing activation aid to the CFA [18]. In addition, a small amount of acidic organic matter was added to reduce the alkalinity of the modified fly ash. Also, the research group has verified the feasibility of a yield-increasing effect of fly ash-based soil conditioner through field trials in the year of 2017 and 2018, but they have only summarized the effect of corn yield increase in two years. Obviously, verifying a new product for two years is not enough. So, in order to investigate the continuity of the yield-increasing effect of fly ash-based soil conditioner and also the applicability to different crops, this study repeated the previous field trials in the same fields in the year of 2019 and set up an additional $30 \mathrm{mu}$ (unit of traditional Chinese land area, approximately equals to $667 \mathrm{~m}^{2}$ ) of wheat test field. At the same time, it is considered that the fly ash-based conditioner contains a small amount of heavy metals; this paper calculated and analyzed the BCF and translocation factor (TF) of $\mathrm{Cr}, \mathrm{As}, \mathrm{Cd}, \mathrm{Hg}$ and $\mathrm{Pb}$ in the corn experimental field and assessed their environmental contamination risk. 


\section{Materials and Methods}

\subsection{Raw Materials and Apparatus}

Coal fly ash was obtained from a coal-fired power plant in Inner Mongolia, China, which contains $11.37 \% \mathrm{Al}, 25.93 \% \mathrm{Si}, 4.80 \% \mathrm{Fe}, 3.66 \% \mathrm{Ca}$ and $1.78 \% \mathrm{Mg}$ by weight and also a small amount of $\mathrm{Mn}$, $\mathrm{B}, \mathrm{Cu}, \mathrm{Zn}$ and $\mathrm{Cl}$ [17]. The soil conditioner from CFA in this study was prepared using the method mentioned in the patent [18]. In the soil conditioner, the activated rates of $\mathrm{MgO}, \mathrm{CaO}$ and $\mathrm{SiO}_{2}$ were $43.28 \%, 96.90 \%$ and $78.82 \%$ respectively [17]. The test method of these available components was determined by China NT/T 2272-2012 soil conditioner [19].

Corn and wheat seeds and conventional fertilizers were purchased locally. The fertilizer consists of $\mathrm{N}, \mathrm{P}_{2} \mathrm{O}_{5}$ and $\mathrm{K}_{2} \mathrm{O}$, which were no less than $15 \%$, respectively.

Inductively Coupled Plasma-Mass Spectrometry (ICP-MS, iCAPQc) were used to analyze the solid chemical composition of the CFA, soil and plants. Microwave Digestion System (MDS-6G, Shanghai Xinyi Microwave Chemical Co., Ltd., China) was used to digest plant and soil samples.

\subsection{Experimental Methods}

At harvest, at least five sets of corn yield data in each plot were collected, and then the yield of each plant per mu (unit of traditional Chinese land area, approximately equal to $667 \mathrm{~m}^{2}$ ) was calculated. The wheat yield data came from the average value of ten plants. The following measurements and observations were also made: grains of ten representative plants were selected to analyze the contents of HMs.

Grain samples were collected after the plants had matured. Before chemical analysis, soil samples were air dried and ground ( $<100$ mesh). Then, the corn plants were washed thoroughly with tap water and deionized water to remove the soil. After measuring the height of the plant samples, they were cut and classified into root, stem, lamina and grain. Next, all parts of the plant were dried to constant weight at $70^{\circ} \mathrm{C}$ and then weighed, respectively. Finally, the dried plant samples were cut into pieces, ground into powder and stored at room temperature before detection.

To assess the risk of heavy metal contamination, the values of the bio-concentration factor (BCF) and translocation factor (TF) were calculated and analyzed as the two main parameters for assessing input, accumulation and transfer of HMs in soil [20]. By comparing changes to the BCF and TF caused by the application of fly ash-based soil conditioner, the heavy metal contamination risk of the soil conditioner can be assessed [13].

\subsection{Field Experiments}

To test the continuity and stability of the fly ash-based soil conditioner on plant growth, corn was also chosen for experiments, as in the previous study [17]. Meanwhile, in order to examine the applicability of the soil conditioner, a wheat experiment plot of $30 \mathrm{mu}$ was set up on castano-cinnamon soil near the corn trail field in Chifeng City in China. When exploring the continuity and stability effects of the soil conditioner on the corn, the same two fields were chosen as the farming plots, just as they were in 2017 and 2018. They were of different soil types: castano-cinnamon soil and dark brown soil. It should be noted that the former plot is flat, while the latter plot was located in a hilly area with a slope of about 30 degrees. In order to avoid accidental factors affecting the experimental results, the test fields, the field test methods and fertilization methods were the same as in 2017 and 2018.

In each soil experiment plot for corn, two blank control groups, fertilizer-free and conventional fertilization (N-P-K compound fertilizer), were set for a comparison study. Meanwhile, in order to explore the optimal application rate of soil conditioner in these two soils, applications of the fertilizer of 20, 32 and $40 \mathrm{~kg} / \mathrm{mu}$ and the conditioner of 50 and $100 \mathrm{~kg} / \mathrm{mu}$ were set in the castano-cinnamon soil. In the dark brown soil, applications of the fertilizer of 15,24 and $30 \mathrm{~kg} / \mathrm{mu}$ and the conditioner of 50 and $100 \mathrm{~kg} / \mathrm{mu}$ were set. A control group and an experimental group were set up in the 
castano-cinnamon soil for wheat. The control group was conventionally fertilized (40 kg/mu), and the amount of conditioner applied in the experimental group was set to $50 \mathrm{~kg} / \mathrm{mu}$.

In order to verify the actual yield-increasing performance of the soil conditioner, field experiments began to be conducted on the soil conditioner from 2017.

The specific geographical locations of the test fields are shown in Figure 1. Chifeng City is marked

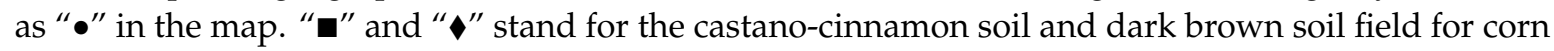
planting, respectively, the areas of which are $5 \mathrm{mu}$, and " $\mathbf{\Delta}$ " represents the wheat planting field, which is a $30 \mathrm{mu}$ castano-cinnamon soli field.

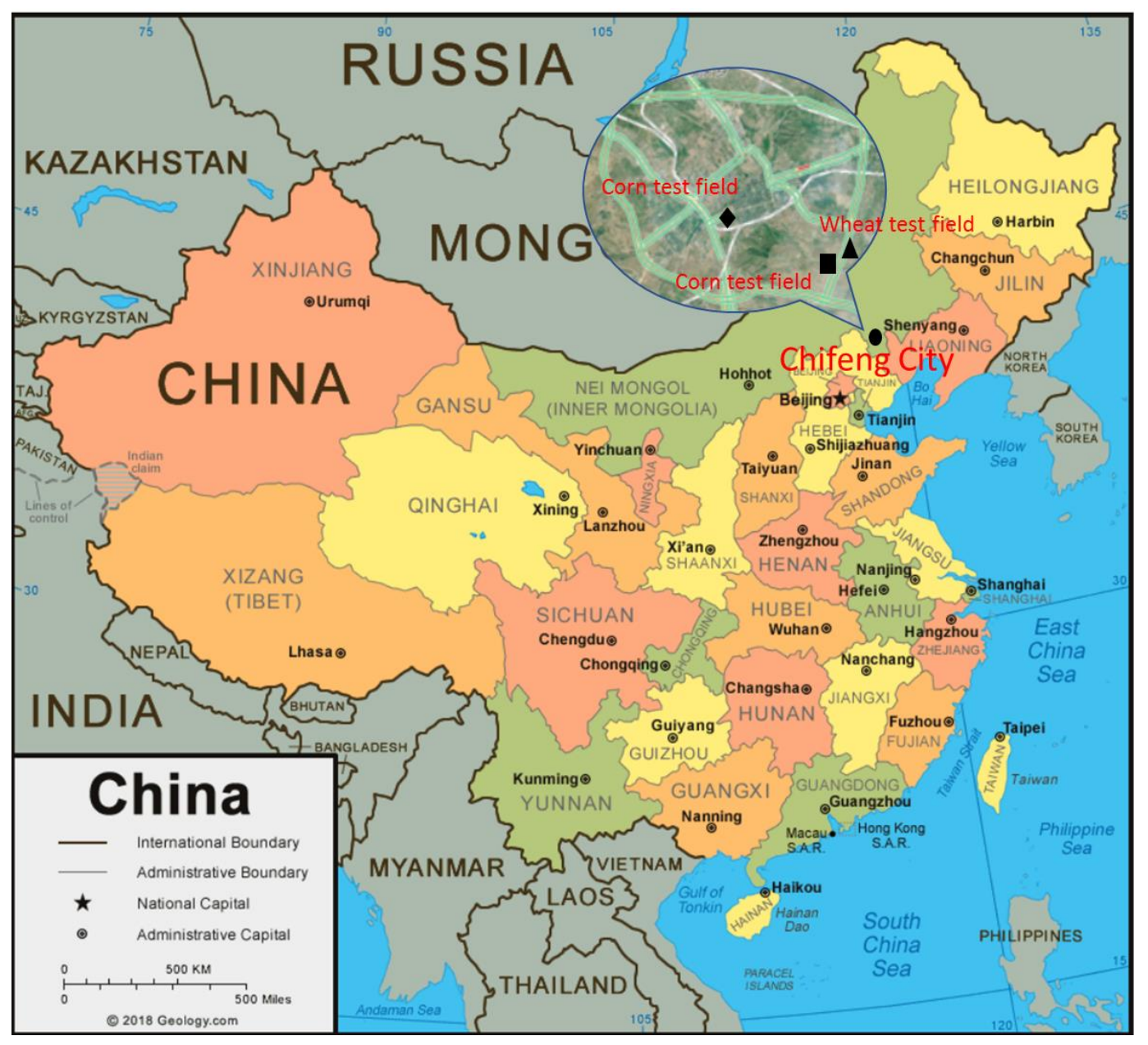

Figure 1. The specific geographical location of the test fields.

\section{Results and Discussion}

\subsection{Results of Field Experiments}

\subsubsection{Castano-Cinnamon Test Results}

Table 1 shows the yield data for corn planted in castano-cinnamon soil in 2019. Table 2 shows the comparison of three-year corn yield-increase rates in castano-cinnamon soil. 
Table 1. The yield data of corn planted in castano-cinnamon soil for 2019.

\begin{tabular}{ccccc}
\hline Groups & $\begin{array}{c}\text { Average Weight of } \\
\text { Ten Corn } \\
\text { Plants/kg }\end{array}$ & $\begin{array}{c}\text { Average Yield Per } \\
\text { mu/kg }\end{array}$ & $\begin{array}{c}\text { Yield-Increase } \\
\text { Rate 1/\% }\end{array}$ & $\begin{array}{c}\text { Yield-Increase } \\
\text { Rate 2/\% }\end{array}$ \\
\hline Blank Control (BC) & 1.113 & 439.71 & 0.00 & -22.42 \\
Conventional Fertilization (CF, 40 kg/mu) & 1.435 & 566.77 & 28.90 & 0.00 \\
CF + Soil Conditioner (SC, 100 kg/mu) & 1.506 & 590.93 & 34.39 & 4.26 \\
$80 \%$ of CF + SC & 1.457 & 571.76 & 30.03 & 0.88 \\
$50 \%$ of CF + SC & 1.448 & 568.02 & 29.18 & 0.22 \\
$80 \%$ of CF + 50\% of SC & 1.470 & 580.73 & 32.07 & 2.46 \\
\hline
\end{tabular}

Note: Yield-increase rate 1 and Yield-increase rate 2 are based on blank and conventional fertilization, respectively.

Table 2. Yield-increase rates of corn planted in castano-cinnamon soil for three years.

\begin{tabular}{|c|c|c|c|c|c|c|}
\hline Groups & $\begin{array}{l}\text { Yield-Increase } \\
\text { Rate } 1 \text { for } \\
2019 / \%\end{array}$ & $\begin{array}{l}\text { Yield-Increase } \\
\text { Rate } 2 \text { for } \\
\text { 2019/\% }\end{array}$ & $\begin{array}{l}\text { Yield-Increase } \\
\text { Rate } 1 \text { for } \\
\text { 2018/\% }\end{array}$ & $\begin{array}{l}\text { Yield-Increase } \\
\text { Rate } 2 \text { for } \\
2018 / \%\end{array}$ & $\begin{array}{l}\text { Yield-Increase } \\
\text { Rate } 2 \text { for } \\
2017 / \%\end{array}$ & $\begin{array}{l}\text { Yield-Increase } \\
\text { Rate } 2 \text { for } \\
2017 / \%\end{array}$ \\
\hline Blank Control (BC) & 0.00 & -22.42 & 0.00 & -8.27 & 0.00 & -1.18 \\
\hline $\begin{array}{l}\text { Conventional Fertilization } \\
(\mathrm{CF}, 40 \mathrm{~kg} / \mathrm{mu})\end{array}$ & 28.90 & 0.00 & 9.02 & 0.00 & 1.20 & 0.00 \\
\hline $\begin{array}{l}\text { CF + Soil Conditioner } \\
(\mathrm{SC}, 100 \mathrm{~kg} / \mathrm{mu})\end{array}$ & 34.39 & 4.26 & 24.18 & 13.91 & 10.05 & 8.75 \\
\hline $50 \%$ of $\mathrm{CF}+\mathrm{SC}$ & 29.18 & 0.22 & 65.98 & 52.25 & 11.24 & 9.93 \\
\hline $80 \%$ of $\mathrm{CF}+50 \%$ of $\mathrm{SC}$ & 32.07 & 2.46 & 15.99 & 6.40 & 11.48 & 10.17 \\
\hline
\end{tabular}

Note: Yield-increase rate 1 and Yield-increase rate 2 are based on blank and conventional fertilization, respectively. Yield-increase rate 1 and 2 for 2017 and 2018 is quoted from a report by our team [17].

As can be seen from the tables above, the application of fly ash-based soil conditioner in castano-cinnamon soil for three consecutive years was able to steadily and continuously increase the corn yield. Over three years, the average increase rate was $11.0 \%$, especially in 2017 and 2018 . Corn yield increased significantly with the highest increase rate being $52.25 \%$, as was speculated to be the result due to the interaction between errors in sample collection or the synergy between fertilizers and low soil topography, which enriched the fertilizer water. The specific reasons need to be further studied, but the outstanding effect of increasing yield was undeniable. In 2019, yield-increase rate 2 was declined, with the highest increase rate being $4.26 \%$, but yield-increase rate 1 remained stable with a high level. Comparing the three-year corn yield data of blank control (BC) and conventional fertilization (CF), it can be found that the yield-increase rate 1 was $1.20 \%, 9.02 \%$, and $28.90 \%$ in 2017 , 2018,2019 , respectively. It could be speculated that the traditional fertilizer accumulated for years in the early stage of the BC plot was gradually being consumed, and fertility was gradually decreasing. Under this circumstance, the yield-increasing effect of traditional fertilizers became more and more significant. Comparing the three-year corn yield data of CF and CF + SC (soil conditioner), it can be found yield-increase rate 2 for 2017 and 2018 is about 10\%, while in 2019 it fell to below 5\%. It was speculated that after the two-year application of soil conditioner, medium trace elements in the soil had been able to meet the needs of crop growth, so the effect of re-application on yield increase became minimal. Moreover, 50\% of CF + SC in 2019 could still maintain a higher yield, indicating that the accumulated fertilizer in the soil before 2019 plus the newly added $20 \mathrm{~kg}$ fertilizer, together with the nutrients in the soil conditioner, constituted the nutritional balance required for plant growth. This is subject to further verification.

In 2018, the feasibility of soil conditioner for increasing the yield of potatoes was tested, and the results showed that both the yield and quality of potato have been greatly improved by soil conditioner [17]. In order to further test whether the soil conditioner has a yield-increasing effect on a variety of crops, a field experiment for wheat was added in 2019. Table 3 shows the characteristics and yield data of wheat grown in castano-cinnamon soil in 2019. 
Table 3. The characteristics and yield data of wheat planted in castano-cinnamon soil in 2019.

\begin{tabular}{cccccc}
\hline Groups & $\begin{array}{c}\text { Plant } \\
\text { Height/cm }\end{array}$ & $\begin{array}{c}\text { Ear } \\
\text { Length/cm }\end{array}$ & $\begin{array}{c}\text { Single Ear } \\
\text { Weight/g }\end{array}$ & $\begin{array}{c}\text { Number of } \\
\text { Grains Per Ear }\end{array}$ & $\begin{array}{c}\text { Hundred-Grain } \\
\text { Wet Weight/kg }\end{array}$ \\
\hline Conventional Fertilization $(\mathrm{CF}, 40 \mathrm{~kg} / \mathrm{mu})$ & 81.35 & 6.13 & 1.53 & 27.43 & 3.71 \\
$\mathrm{CF}+$ Soil Conditioner $(50 \mathrm{~kg} / \mathrm{mu})$ & 88.73 & 7.79 & 2.16 & 34.06 & 4.12 \\
Increase rate & $8.73 \%$ & $27.08 \%$ & $41.10 \%$ & $24.17 \%$ & $10.85 \%$ \\
\hline
\end{tabular}

From Table 3, it can be seen that the application of fly ash-based soil conditioner was able to greatly increase the wheat yield in the test field of castano-cinnamon soil. The grain yield monitoring data revealed that the wheat yield increased by $14.95 \%$. At the same time, traits of wheat have improved significantly. The height of plant as well as the length of ear increased significantly, and wheat grain became fuller. Furthermore, the mass of single wheat ear increased by $41.10 \%$, and the number of grains per ear increased by $24.17 \%$. Judging from the field tests of wheat and corn on castano-cinnamon soil, it can be found that the yield-increasing effect of soil conditioner is not limited to a single crop but is widely adaptable.

\subsubsection{Dark Brown Soil Test Results}

Table 4 shows the yield data for corn planted in dark brown soil in 2019. Table 5 shows the comparison of three-year corn yield-increase rates in dark brown soil.

Table 4. The yield data of corn planted in dark brown soil for 2019.

\begin{tabular}{ccccc}
\hline Groups & $\begin{array}{c}\text { Average Weight of } \\
\text { Ten Corn } \\
\text { Plants/kg }\end{array}$ & $\begin{array}{c}\text { Average Yield Per } \\
\text { mu/kg }\end{array}$ & $\begin{array}{c}\text { Yield-Increase } \\
\text { Rate 1/\% }\end{array}$ & $\begin{array}{c}\text { Yield-Increase } \\
\text { Rate 2/\% }\end{array}$ \\
\hline Blank Control (BC) & 1.179 & 465.55 & 0.00 & -3.90 \\
Conventional Fertilization (CF, 30 kg/mu) & 1.226 & 484.43 & 4.06 & 0.00 \\
CF + Soil Conditioner (SC, 100 kg/mu) & 1.375 & 543.13 & 16.66 & 39.82 \\
80\% of CF + SC & 1.648 & 650.94 & 26.74 & 34.37 \\
$50 \%$ of CF + SC & 1.494 & 590.03 & 21.80 \\
$80 \%$ of CF + 50\% of SC & 1.484 & 586.35 & 25.95 & 21.04 \\
\hline
\end{tabular}

Note: Yield-increase rate 1 and Yield-increase rate 2 are based on blank and conventional fertilization respectively.

Table 5. Yield-increase rates of corn planted in dark brown soil for three years.

\begin{tabular}{|c|c|c|c|c|c|c|}
\hline Groups & $\begin{array}{l}\text { Yield-Increase } \\
\text { Rate } 1 \text { for } \\
\text { 2019/\% }\end{array}$ & $\begin{array}{l}\text { Yield-Increase } \\
\text { Rate } 2 \text { for } \\
2019 / \%\end{array}$ & $\begin{array}{c}\text { Yield-Increase } \\
\text { Rate } 1 \text { for } \\
\text { 2018/\% }\end{array}$ & $\begin{array}{l}\text { Yield-Increase } \\
\text { Rate } 2 \text { for } \\
2018 / \%\end{array}$ & $\begin{array}{c}\text { Yield-Increase } \\
\text { Rate } 2 \text { for } \\
2017 / \%\end{array}$ & $\begin{array}{l}\text { Yield-Increase } \\
\text { Rate } 2 \text { for } \\
2017 / \%\end{array}$ \\
\hline Blank Control (BC) & 0.00 & -3.90 & 0.00 & -8.33 & 0.00 & -3.99 \\
\hline $\begin{array}{l}\text { Conventional Fertilization } \\
\text { (CF, } 30 \mathrm{~kg} / \mathrm{mu})\end{array}$ & 4.06 & 0.00 & 9.09 & 0.00 & 4.16 & 0.00 \\
\hline $\begin{array}{l}\text { CF + Soil Conditioner } \\
(\mathrm{SC}, 100 \mathrm{~kg} / \mathrm{mu})\end{array}$ & 16.66 & 12.12 & 19.19 & 9.26 & 6.11 & 1.87 \\
\hline $50 \%$ of $\mathrm{CF}+\mathrm{SC}$ & 26.74 & 21.80 & 17.85 & 8.03 & 7.08 & 2.81 \\
\hline $80 \%$ of $\mathrm{CF}+50 \%$ of SC & 25.95 & 21.04 & 21.81 & 11.66 & 8.84 & 4.49 \\
\hline
\end{tabular}

Note: Yield-increase rate 1 and Yield-increase rate 2 are based on blank and conventional fertilization respectively. Yield-increase rate 1 and 2 for 2017 and 2018 is quoted from a report by our team [17].

As can be seen from the tables above, the application of fly ash-based soil conditioner in dark brown soil for three consecutive years was able to increase corn yield steadily and continuously. The growth rate has increased year by year, with an average increase of $11.2 \%$ over three years. Yield increase was the most obvious in 2019, of which the largest increase occurred in the group of $80 \% \mathrm{CF}$ and $100 \%$ SC, with increase rates of $39.82 \%$ and $34.37 \%$, compared with the conventional fertilization group and the blank control group, respectively. The field test results of dark brown soil in 2017 and 2018 showed that the optimal treatment was $80 \%$ of CF $+50 \%$ of SC, which still significantly increased corn yield in 2019 by $25.95 \%$ and $21.04 \%$, respectively, compared with the conventional fertilization group and the blank control group. It is speculated that conventional fertilization can be reduced 
to $80 \%$, and conditioners can be reduced by up to $50 \%$. Compared with the castano-cinnamon soil test field, the dark brown soil test field showed no decline in corn yield increase in 2019. This should be attributed to the steep terrain of the dark brown soil test field, which led to the loss of fertilizers (chemical fertilizers and soil conditioner), and the cumulative effect is not obvious.

\subsection{Risk of Heavy Metal Contamination}

In order to fully investigate the potential environmental impact of fly ash-based soil conditioner, this section aimed to track and analyze the HMs in corn and soil. The behavior of HMs had been briefly detected and analyzed in 2017, and the results showed that the HMs had not been significantly enriched in corn stalks after applying the soil conditioner. Considering the accumulation of HMs with the increase in the application amount of fly ash-based soil conditioner, based on the work conducted in 2017, the conventional fertilization group and the maximum amount of conditioner application group would continue to be selected as representatives in 2019 . The heavy metal contents in various parts of selected corn plants were also compared and analyzed. Furthermore, the values of the bio-concentration factor (BCF) and translocation factor (TF) were calculated and analyzed because they are the two main parameters for assessing the input, accumulation and transfer of HMs in soil [20].

One of the first things we needed to briefly calculate was the theoretical input of HMs caused by the conditioner. In the above field tests, the general tillage depth was about $20 \mathrm{~cm}$, and based on $667 \mathrm{~m}^{2}$ per $\mathrm{mu}$, the actual cultivated soil volume was $133.4 \mathrm{~m}^{3}$. The general soil bulk density was $1.1 \sim 1.4 \mathrm{~g} / \mathrm{cm}^{3}$ (choosing $1.3 \mathrm{~g} / \mathrm{cm}^{3}$ ). Therefore, the actual cultivated soil was $173,420 \mathrm{~kg} / \mathrm{mu}$, and the maximum application amount of soil conditioner was $100 \mathrm{~kg} / \mathrm{mu}$, only accounting for $0.06 \%$. Below, Table 6 shows the test results of five HMs in fly ash-based soil conditioner, and Table 7 shows the theoretical increase in soil heavy metal concentrations due to the application of soil conditioner within three years and China's risk control standard for soil contamination of agriculture land of GB 15618-2018.

Table 6. The test results of five heavy metals in fly ash-based soil conditioners.

\begin{tabular}{cccccc}
\hline & $\mathbf{C r}$ & As & $\mathbf{C d}$ & $\mathbf{H g}$ & $\mathbf{P b}$ \\
\hline $\mathrm{mg} / \mathrm{kg}$ & 29.01 & 41.39 & 0.25 & 0.23 & 15.08 \\
\hline $\mathrm{g} / 100 \mathrm{~kg}$ & 2.90 & 4.14 & 0.025 & 0.023 & 1.51 \\
\hline
\end{tabular}

Note: This test result is issued by the Testing Center of Tsinghua University.

Table 7. The theoretical increase of soil heavy metal concentrations within three years.

\begin{tabular}{cccccc}
\hline & $\mathbf{C r}$ & As & $\mathbf{C d}$ & $\mathbf{H g}$ & $\mathbf{P b}$ \\
\hline $\mathrm{mg} / \mathrm{kg}$ & 0.050 & 0.072 & 0.00044 & 0.00039 & 0.026 \\
\hline $\mathrm{Limit} / \mathrm{mg} / \mathrm{kg}$ & 150 & 20 & 0.3 & 0.5 & 70 \\
\hline
\end{tabular}

Note: Limit represents the soil environmental quality assessment indicator limits of GB 15618-2018.

As can be seen from the table above, when the tillage depth is $20 \mathrm{~cm}$ and the application amount of soil conditioner is $100 \mathrm{~kg} / \mathrm{mu}$, it was equivalent that $2.90 \mathrm{~g} \mathrm{Cr}, 4.14 \mathrm{~g} \mathrm{As}, 0.025 \mathrm{~g} \mathrm{Cd}, 0.023 \mathrm{~g} \mathrm{Hg}$ and $1.51 \mathrm{~g} \mathrm{~Pb}$ would subsequently enter the $173,420 \mathrm{~kg}$ soil. Based on cumulative input over the past three years, it could be calculated that the theoretical increases of soil heavy metal contents were only $0.050 \mathrm{mg} / \mathrm{kg}, 0.072 \mathrm{mg} / \mathrm{kg}, 0.00044 \mathrm{mg} / \mathrm{kg}, 0.00039 \mathrm{mg} / \mathrm{kg}$ and $0.026 \mathrm{mg} / \mathrm{kg}$, respectively, which were far below the soil environmental quality assessment indicator limits of GB 15618-2018. It can be preliminarily inferred that the potential contamination risk of HMs in the fly ash-based soil conditioner being transferred into the soil is negligible and can be ignored. Tables 8 and 9 indicate that the application of soil conditioner for three consecutive years did not significantly increase the heavy metal contents in the castano-cinnamon soil and dark brown soil. Of course, more specific calculation and analysis of HMs in corn plants have been done as well. 
Table 8. Contents of heavy metals in castano-cinnamon soil.

\begin{tabular}{cccccc}
\hline & Cr & As & Cd & Hg & Pb \\
\hline CF & 21.06 & 6.74 & 0.15 & 0.14 & 10.93 \\
\hline CF + SC & 24.97 & 8.95 & 0.11 & 0.13 & 11.24 \\
\hline
\end{tabular}

Table 9. Contents of heavy metals in dark brown soil.

\begin{tabular}{cccccc}
\hline & Cr & As & Cd & Hg & Pb \\
\hline CF & 32.95 & 5.02 & 0.67 & 0.09 & 16.76 \\
\hline CF + SC & 44.81 & 4.99 & 0.76 & 0.12 & 17.59 \\
\hline
\end{tabular}

\subsubsection{Contents of Heavy Metals in Corn Plants}

Table 10 below shows the test results of heavy metal contents in corn on the test field of castano-cinnamon soil.

Table 10. The test results of five heavy metal contents in corn on castano-cinnamon soil.

\begin{tabular}{cccccc}
\hline Groups & $\mathbf{C r}$ & $\mathbf{A s}$ & $\mathbf{C d}$ & $\mathbf{H g}$ & $\mathbf{P b}$ \\
\hline CF-root & 10.62 & 0.71 & 0.07 & 0.03 & 2.06 \\
CF + SC-root & $\uparrow 11.46$ & $\uparrow 0.92$ & $\uparrow 0.09$ & $\downarrow 0.03$ & $\uparrow 4.08$ \\
CF-stem & 7.40 & 0.36 & 0.07 & 0.02 & 1.49 \\
CF + SC-stem & $\downarrow 4.17$ & $\downarrow 0.08$ & $\downarrow 0.01$ & $\downarrow 0.02$ & $\downarrow 0.50$ \\
CF-lamina & 12.54 & 0.81 & 0.13 & 0.08 & 2.61 \\
CF + SC-lamina & $\downarrow 7.56$ & $\uparrow 0.82$ & $\downarrow 0.13$ & $\uparrow 0.09$ & $\uparrow 2.83$ \\
\hline
\end{tabular}

Note: CF is conventional fertilization $(40 \mathrm{~kg} / \mathrm{mu})$ treatment; $\mathrm{CF}+\mathrm{SC}$ is conventional fertilization $(40 \mathrm{~kg} / \mathrm{mu})+$ conditioner $(100 \mathrm{~kg} / \mathrm{mu})$ treatment. The unit of heavy metal content is $\mathrm{mg} / \mathrm{kg}$.

As is shown in the Table 10, compared with conventional fertilization, there was no significant increase of $\mathrm{Cr}, \mathrm{As}, \mathrm{Cd}, \mathrm{Hg}$, and $\mathrm{Pb}$ in the root, stem, and lamina of corn after the application of the soil conditioner in the test field of castano-cinnamon soil. At the root, the contents of $\mathrm{Cr}$, As and $\mathrm{Cd}$ increased slightly by less than $29.5 \%$ and the content of $\mathrm{Hg}$ remained unchanged, while the content of $\mathrm{Pb}$ increased significantly by $98.1 \%$. In general, the application of soil conditioner on castano-cinnamon soil would not significantly enhance the absorption and enrichment of $\mathrm{Cr}, \mathrm{As}, \mathrm{Cd}$ and $\mathrm{Hg}$ by the root of corn. At the stem, the contents of these five HMs all decreased to varying degrees. As for the HMs in lamina, the content of $\mathrm{Cr}$ decreased significantly by $39.7 \%$, and the contents of the remaining HMs were basically flat. Overall, these five HMs were not significantly enriched in any part of the corn after the soil conditioner had been applied in the test field of castano-cinnamon soil. There is no environmental risk for returning straw to the field or for raising livestock.

Below, Table 11 shows the test results of heavy metal contents in corn on the test field of dark brown soil.

Table 11. The test results of five heavy metal contents in corn on dark brown soil.

\begin{tabular}{cccccc}
\hline Groups & Cr & As & Cd & Hg & Pb \\
\hline CF-root & 11.88 & 1.30 & 0.07 & 0.09 & 4.26 \\
CF + SC-root & $\uparrow 12.03$ & $\downarrow 1.06$ & $\downarrow 0.06$ & $\downarrow 0.06$ & $\downarrow 3.68$ \\
CF-stem & 9.89 & 0.31 & 0.07 & 0.08 & 1.57 \\
CF + SC-stem & $\uparrow 12.48$ & $\uparrow 0.41$ & $\uparrow 0.08$ & $\downarrow 0.07$ & $\uparrow 1.90$ \\
CF-lamina & 7.24 & 0.48 & 0.09 & 0.06 & 2.06 \\
CF + SC-lamina & $\uparrow 7.91$ & $\downarrow 0.42$ & $\downarrow 0.08$ & $\downarrow 0.04$ & $\downarrow 1.82$ \\
\hline
\end{tabular}

Note: CF is conventional fertilization $(30 \mathrm{~kg} / \mathrm{mu})$ treatment; CF + SC is conventional fertilization $(30 \mathrm{~kg} / \mathrm{mu})+$ conditioner $(100 \mathrm{~kg} / \mathrm{mu})$ treatment. The unit of heavy metal content is $\mathrm{mg} / \mathrm{kg}$. 
From the data in the table above, compared with conventional fertilization, it can be seen that in the dark brown soil test field, there was no significant increase of $\mathrm{Cr}, \mathrm{As}, \mathrm{Cd}, \mathrm{Hg}$ and $\mathrm{Pb}$ in the root, stem, and lamina of corn after the application of the soil conditioner. At the root, the contents of these five HMs were basically flat. The content of $\mathrm{Cr}$ increased by only $1.2 \%$, while the contents of $\mathrm{As}, \mathrm{Cd}$, $\mathrm{Hg}$, and $\mathrm{Pb}$ showed a downward trend. Generally speaking, the application of soil conditioner on dark brown soil had no obvious effect on the corn root for absorption and enrichment of these five $\mathrm{HMs}$. At the stem, the contents of $\mathrm{As}, \mathrm{Cd}, \mathrm{Hg}$, and $\mathrm{Pb}$ seemed to be basically flat, while the content of $\mathrm{Cr}$ increased slightly. Similarly, the contents of these five HMs in the lamina were almost unchanged. Overall, these five HMs were not significantly enriched in any parts of the corn after the soil conditioner had been applied in the test field of dark brown soil. There is no environmental risk for returning straw to the field or for raising livestock.

In view of the overall results, the application of fly ash-based soil conditioner in the two test fields had no significant effect on the absorption and enrichment of $\mathrm{Cr}, \mathrm{As}, \mathrm{Cd}$ and $\mathrm{Hg}$ by corn. The application of soil conditioner in the castano-cinnamon soil test field might increase the absorption and enrichment of $\mathrm{Pb}$ by the root of corn. In fact, $\mathrm{Pb}$ is most likely to migrate under acidic conditions, while the soil conditioner is alkaline. Theoretically, the application of soil conditioner could inhibit the migration of $\mathrm{Pb}$. As a result, the root of corn grown on dark brown soil reduced the absorption of $\mathrm{Pb}$. Furthermore, the behavior of $\mathrm{Pb}$ in the shoot part of the corn was consistent with that of $\mathrm{Cr}, \mathrm{As}, \mathrm{Cd}$ and $\mathrm{Hg}$, whose contents basically remained unchanged without any significant increase, or even decreased. Therefore, it was speculated that the substantial increase of $\mathrm{Pb}$ in corn root is caused by experimental errors. Subsequent detection of heavy metal contents in corn grains has also been conducted.

\subsubsection{Soil Conditioner Affects Transfer of Heavy Metals in Corn}

$\mathrm{BCF}$ is defined as the ratio of the metal contents in plant parts (including root, stem and lamina) to the exchangeable metal contents in the soil [20]. Larger BCF usually indicates a greater ability of one metal to migrate from soil to plant parts [21]. TF is the ratio of the metal contents in the shoot part (including stem, lamina and fruit) of the plant to the metal contents in the root [20]. The uptake of HMs by plants may be related to the bioavailability of these metals and the physic-chemical properties of the soil [22]. Based on the research by Mujtaba et al. [13], lower TF value always represents a lower degree of food chain enrichment and lower risk of heavy metal contamination. By calculating BCF and TF values and comparing their changes with different treatments, the effects of soil conditioner on HMs transfer can be explored to assess the risk of HMs contamination. Figures 2 and 3 show the BCF and TF values of corn grown in castano-cinnamon soil.

As is shown in the Figure 2, after applying the soil conditioner to the castano-cinnamon soil test field, the $\mathrm{BCF}_{\text {root }}\left(\mathrm{BCF}\right.$ between root and soil), $\mathrm{BCF}_{\text {stem }}\left(\mathrm{BCF}\right.$ between stem and soil) and $\mathrm{BCF}_{\text {lam }}$ (BCF between lamina and soil) of $\mathrm{Cr}$ and As showed a downward trend, with a decrease of $83 \%$ to $4 \%$. The $\mathrm{BCF}_{\text {root}}, \mathrm{BCF}_{\text {stem }}$ and $\mathrm{BCF}_{\text {lam }}(\mathrm{BCFs})$ of $\mathrm{Hg}$ reminded almost unchanged. As for $\mathrm{Pb}$, it was previously speculated that the experimental error led to an artificial increase of $\mathrm{Pb}$ in corn root, which further led to the increase of the $\mathrm{BCF}_{\text {root }}$ of $\mathrm{Pb}$. The $\mathrm{BCF}_{\text {root }}$ and $\mathrm{BCF}_{\text {lam }}$ of $\mathrm{Cd}$ increased significantly, while the $\mathrm{BCF}_{\text {stem }}$ of $\mathrm{Cd}$ dropped sharply. In fact, the differences of $\mathrm{Cd}$ contents in corn root and lamina are not obvious. It was speculated that the difference in soil background was the main reason for the increase of the $\mathrm{BCF}_{\text {root }}$ and $\mathrm{BCF}_{\text {lam }}$ of $\mathrm{Cd}$.

From the data shown in Figure 3, it can be seen that after the application of soil conditioner in the castano-cinnamon test field, the TF values of these five HMs in corn all changed significantly. On the whole, the $\mathrm{TF}_{\text {stem }}$ ( $\mathrm{TF}$ between stem and root) of $\mathrm{Pb}, \mathrm{Cd}$, As and $\mathrm{Cr}$ decreased sharply, with a decrease range of $93 \%$ to $47 \%$, while the $\mathrm{TF}_{\text {stem }}$ of $\mathrm{Hg}$ remained almost unchanged. The $\mathrm{TF}_{\text {lam }}$ ( $\mathrm{TF}$ between lamina and root) of $\mathrm{Cr}, \mathrm{As}, \mathrm{Cd}$ and $\mathrm{Pb}$ showed a downward trend, with a decrease of $45 \%$ to $19 \%$, and the descending order was $\mathrm{Pb}>\mathrm{Cr}>\mathrm{As}>\mathrm{Cd}$. The $\mathrm{TF}_{\text {lam }}$ of $\mathrm{Hg}$ rose slightly by $16 \%$, which might be related to diverse cultivation methods, environmental differences, the special transportation mode of $\mathrm{Hg}$ in corn and experimental errors. 

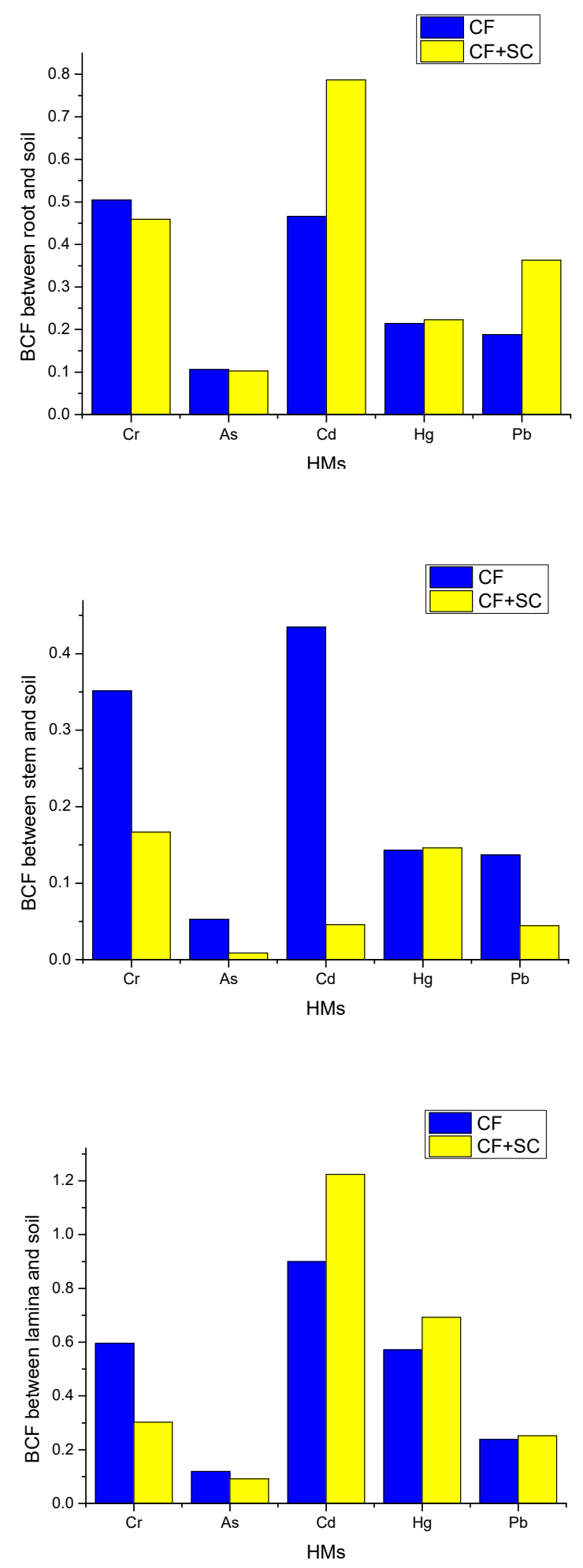

Figure 2. $\mathrm{BCF}$ values of corn grown in castano-cinnamon soil. Note: The left is $\mathrm{BCF}_{\text {root, }}$ the middle is $\mathrm{BCF}_{\text {stem }}$ and the right is $\mathrm{BCF}_{\text {lam }} ; \mathrm{CF}$ is conventional fertilization $(40 \mathrm{~kg} / \mathrm{mu})$ treatment; $\mathrm{CF}+\mathrm{SC}$ is conventional fertilization $(40 \mathrm{~kg} / \mathrm{mu})+$ conditioner $(100 \mathrm{~kg} / \mathrm{mu})$ treatment. 

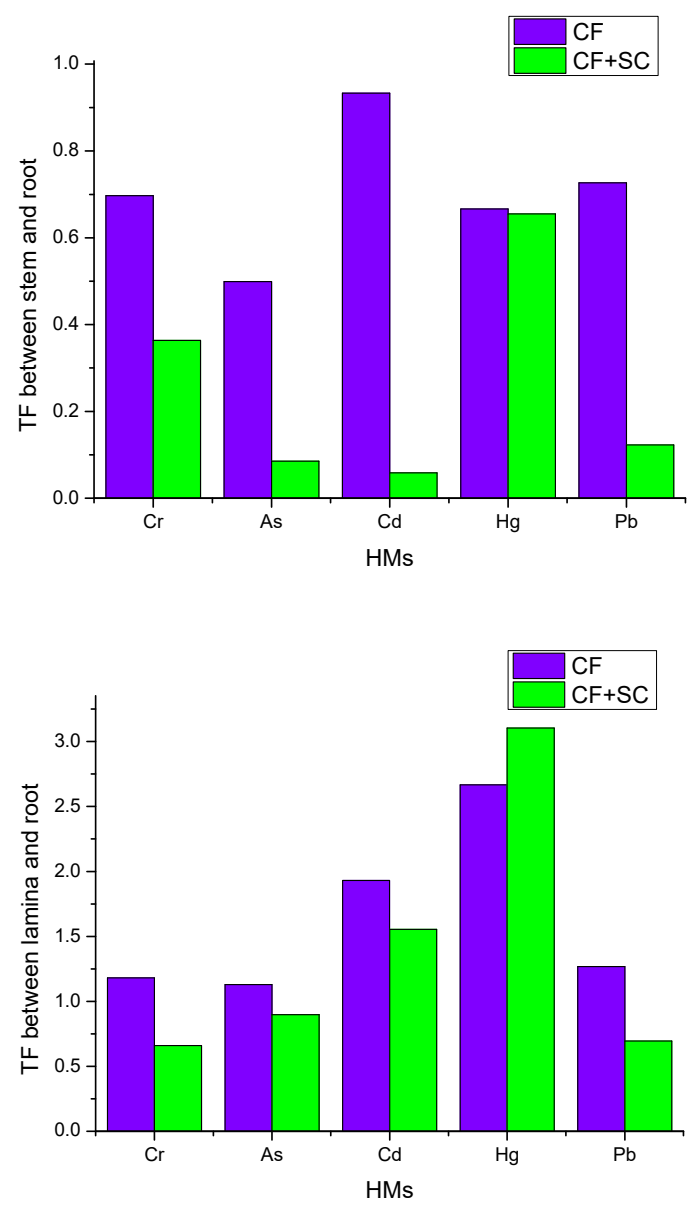

Figure 3. $\mathrm{TF}$ values of corn grown in castano-cinnamon soil. Note: The left is $\mathrm{TF}_{\text {stem }}$ and right is $\mathrm{TF}_{\text {lam }}$; $\mathrm{CF}$ is conventional fertilization $(40 \mathrm{~kg} / \mathrm{mu})$ treatment; $\mathrm{CF}+\mathrm{SC}$ is conventional fertilization $(40 \mathrm{~kg} / \mathrm{mu})+$ conditioner $(100 \mathrm{~kg} / \mathrm{mu})$ treatment.

Figures 4 and 5 show the BCF and TF values of corn grown in dark brown soil.

As is shown in the Figure 4, after applying the soil conditioner to the dark brown soil test field, the $\mathrm{BCF}_{\text {root }}, \mathrm{BCF}_{\text {stem }}$ and $\mathrm{BCF}_{\text {lam }}(\mathrm{BCFs})$ of $\mathrm{Pb}, \mathrm{Cr}$, As and $\mathrm{Cd}$ basically showed a downward trend, with a decrease range of $26 \%$ to $-12 \%$. The BCFs of $\mathrm{Hg}$ dropped significantly, with a decrease of more than $38 \%$. From the data shown in Figure 5, it can be seen that after applying the conditioner in the dark brown soil test field, a large proportion of the TF values of these five HMs in corn did not change significantly. Specifically, $\mathrm{TF}_{\text {stem }}$ of $\mathrm{Cr}, \mathrm{Cd}$ and $\mathrm{Hg}$ increased slightly with a range of $25 \%$ to $17 \%$, while the $\mathrm{TF}_{\text {stem }}$ of As and $\mathrm{Pb}$ rose by $60 \%$ and $40 \%$, respectively, probably due to lower background concentration and experimental errors. $\mathrm{TF}_{\mathrm{lam}}$ of $\mathrm{As}, \mathrm{Pb}, \mathrm{Cr}$ and $\mathrm{Hg}$ in corn was almost unchanged, with a variation range of $7.8 \%$ to $-1.7 \%$. Although the $\mathrm{TF}_{\mathrm{lam}}$ of $\mathrm{Cd}$ changed the most, its growth was only $11 \%$.

In view of the overall results, the application of the soil conditioner had a significant effect on the $\mathrm{BCF}$ and $\mathrm{TF}$ values of $\mathrm{As}, \mathrm{Pb}, \mathrm{Cr}, \mathrm{Cd}$ and $\mathrm{Hg}$ in the castano-cinnamon soil test field, in which the $\mathrm{TF}_{\text {stem }}$ and $\mathrm{TF}_{\text {lam }}(\mathrm{TFs})$ values showed a downward trend. Excluding the effects of sampling and testing errors, the BCFs of these five HMs should theoretically remain unchanged or even decrease. The reason for this is that the soil conditioner agent is alkaline and has a strong adsorption capacity, which can firmly immobilize the HMs in the soil [13]. The decrease in BCFs and TFs means that the application of soil conditioner limits the transfer of HMs in soil, as well as corn, and reduces the risk of heavy metal contamination. The soil conditioner contains a large amount of active silicon, which is an important element for building plants. Also, silicon can promote plant synthesis and release chelating agents [23], thereby forming hydroxyaluminosilicate precipitation to limit the transfer of HMs [24]. The increased 
content of silicon in corn stalks, which were specifically tested, and the changes in the TFs of HMs also corroborate this view. In the dark brown soil test field, the BCFs of these five HMs all showed a downward trend, while the TFs of these five HMs remained basically flat or slightly increased with the application of the soil conditioner (deviations were within 10\%). After excluding some sampling and testing errors, the landform of the test field and the change of corn mass were analyzed. As a result, it is possible that the inclined terrain and natural rainfall caused the conditioner not to be completely absorbed in the plot, which would reduce the ability of the soil conditioner to limit HMs transfer.
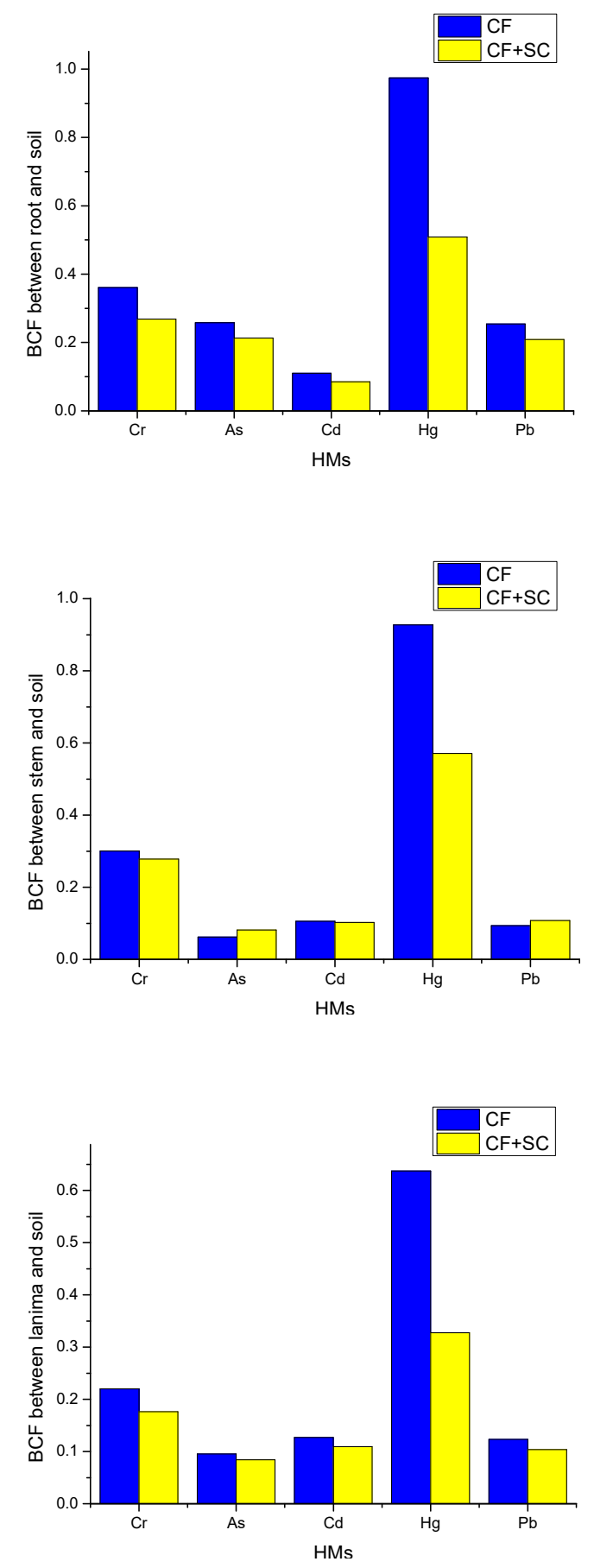

Figure 4. $\mathrm{BCF}$ values of corn grown in dark brown soil. Note: The left is $\mathrm{BCF}_{\text {root }}$, the middle is $\mathrm{BCF}_{\text {stem }}$ and the right is $\mathrm{BCF}_{\text {lam }}$; $\mathrm{CF}$ is conventional fertilization $(30 \mathrm{~kg} / \mathrm{mu})$ treatment; $\mathrm{CF}+\mathrm{SC}$ is conventional fertilization $(30 \mathrm{~kg} / \mathrm{mu})+$ conditioner $(100 \mathrm{~kg} / \mathrm{mu})$ treatment. 

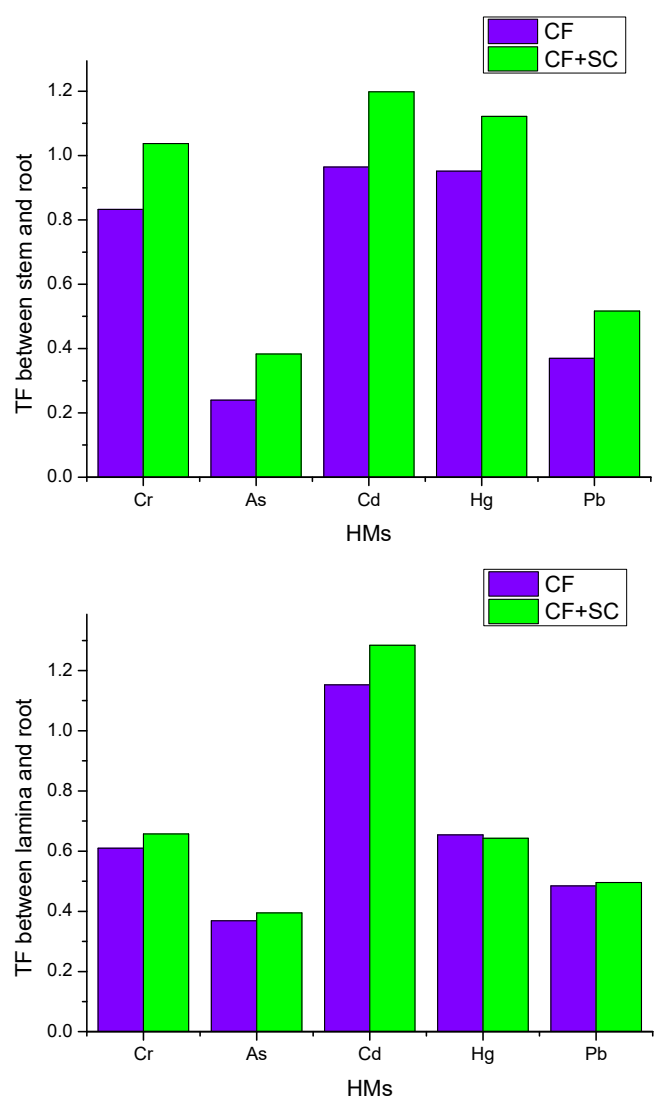

Figure 5. TF values of corn grown in dark brown soil. Note: The left is $\mathrm{TF}_{\text {stem }}$ and right is $\mathrm{TF}_{\text {lam; }} \mathrm{CF}$ is conventional fertilization $(30 \mathrm{~kg} / \mathrm{mu})$ treatment; $\mathrm{CF}+\mathrm{SC}$ is conventional fertilization $(30 \mathrm{~kg} / \mathrm{mu})+$ conditioner $(100 \mathrm{~kg} / \mathrm{mu})$ treatment.

\subsubsection{Detection of Heavy Metal in Corn Grain}

As the contents of some HMs in corn grains are lower than the detection limit, it is difficult to perform calculation and contrast analysis of $\mathrm{TF}_{\text {fru }}$ ( $\mathrm{TF}$ between fruit and root). Since the potential hazards of HMs in soil conditioner are a hot issue when soil conditioner is utilized for agriculture, accurate quality examinations of all the corn samples were conducted after the harvests in 2017 and 2018. The examination results of 2018 are shown below.

As shown in Tables 12 and 13, after the application of soil conditioner, the contents of HMs in the corn grains did not change significantly in 2018, and the quality of the corn grains totally meets the Chinese and EU standards. Furthermore, compared with the examination results of 2017 [17], there was no obvious enrichment of HMs in corn grains. Of course, continuous tracking detection is still necessary.

Table 12. The contents of heavy metals in corn grains planted on castano-cinnamon soil after applying soil conditioner in 2018.

\begin{tabular}{cccccc}
\hline Elements & Pb & Cd & Hg & As & Cr \\
\hline Blank Control (BC) & $/$ & $/$ & $/$ & $/$ & 0.450 \\
Conventional Fertilization(CF) & $/$ & $/$ & $/$ & $/$ & 0.344 \\
CF + Soil Conditioner (SC) & $/$ & $/$ & $/$ & $/$ & 0.438 \\
80\% of CF + SC & $/$ & $/$ & $/$ & $/$ & 0.544 \\
50\% of CF + SC & $/$ & $/$ & $/$ & $/$ & 0.367 \\
80\% of CF + 50\% of SC & $/$ & $/$ & $/$ & $/$ & 0.489 \\
\hline China food safety standard of GB 2762-2012 & 0.2 & 0.1 & 0.02 & 0.5 & 1.0 \\
European food safety standard of EC 1881/2006 & 0.2 & 0.1 & $/$ & $/$ & $/$ \\
\hline
\end{tabular}


Table 13. The contents of heavy metals in corn grains planted on dark brown soil after applying soil conditioner in 2018.

\begin{tabular}{cccccc}
\hline Elements & Pb & Cd & Hg & As & Cr \\
\hline Blank Control (BC) & $/$ & 0.002 & $/$ & 0.02 & 0.480 \\
Conventional Fertilization(CF) & $/$ & 0.001 & $/$ & $/$ & 0.552 \\
CF + Soil Conditioner (SC) & 0.02 & 0.002 & $/$ & $/$ & 0.546 \\
80\% of CF + SC & $/$ & 0.002 & $/$ & $/$ & 0.596 \\
50\% of CF + SC & $/$ & 0.001 & $/$ & $/$ & 0.291 \\
80\% of CF + 50\% of SC & 0.02 & 0.002 & $/$ & $/$ & 0.558 \\
\hline China food safety standard of GB 2762-2012 & 0.2 & 0.1 & 0.02 & 0.5 & 1.0 \\
European food safety standard of EC 1881/2006 & 0.2 & 0.1 & $/$ & $/$ & $/$ \\
\hline
\end{tabular}

\section{Conclusions}

A new type of inorganic soil conditioner, synthesized by utilizing CFA, was used as experiment material, and a series of field experiments were conducted to verify the continuity and stability of the yield-increasing effect of this fly ash-based soil conditioner and analyze the risk of heavy metal contamination. The main conclusions are as follows:

(1) Field tests on different types of soils and crops for three consecutive years show that new fly ash-based soil conditioner has broad adaptability and stability. For corn grown in castano-cinnamon soil and dark brown soil, the application of new fly ash-based soil conditioner steadily and continuously increased corn yield by more than $10 \%$ for three years. At the same time, the yield of wheat planted on castano-cinnamon soil increased by $15 \%$ based on a one-year field test. Overall, the amount of conventional fertilizer used can be reduced to a certain extent (20-50\% in terms of weight) when the soil conditioner is added with fertilizer.

(2) After applying the soil conditioner on castano-cinnamon soil and dark brown soil, the contents of $\mathrm{As}, \mathrm{Pb}, \mathrm{Cr}, \mathrm{Cd}$ and $\mathrm{Hg}$ in various parts of corn did not increase significantly. In addition, most of the BCFs and TFs of these five HMs remained unchanged or even declined. Furthermore, the application of new fly ash-based soil conditioner on castano-cinnamon soil is able to limit the migration of HMs from soil to plant so as to greatly reduce the risk of HMs contamination. The application of new fly ash-based soil conditioners on dark brown soil did not significantly increase the bioavailability of HMs. On the whole, the potential contamination risk of HMs contained in new fly ash-based soil conditioner to the soil is negligible and can be ignored.

Author Contributions: Conceptualization, S.M.; Investigation, X.Z. and J.S.; Writing-original draft, Y.O.; Writing-review \& editing, Y.O., X.W. and Y.Z. All authors have read and agreed to the published version of the manuscript.

Funding: This research was funded by Consulting Research Project of Chinese Academy of Engineering: Ningxia Energy Chemical Solid Waste Disposal and Resource Utilization Strategy Research (2019NXZD4); Inner Mongolia Science and Technology Major Project: Preparation and Application Demonstration of Fly Ash-based Soil Conditioner; Inner Mongolia Daihai Power Generation Co., Ltd.: Study on the Occurrence Rule and Safe Removal and Disposal Methods of Typical Heavy Metals in Fly Ash; Xilingol Professional College: Study on Preparation and Application Technology of Fly Ash-based Grassland Restoration; Materials Research on Preparation and Application Technology of Fly Ash-based Desert Improvement Materials.

Acknowledgments: This work was supported by Inner Mongolia Science and Technology Major Project: Preparation and Application Demonstration of Fly Ash-based Soil Conditioner; Consulting Research Project of Chinese Academy of Engineering: Ningxia Energy Chemical Solid Waste Disposal and Resource Utilization Strategy Research (2019NXZD4); Inner Mongolia Daihai Power Generation Co., Ltd.: Study on the Occurrence Rule and Safe Removal and Disposal Methods of Typical Heavy Metals in Fly Ash and Xilingol Professional College: Study on Preparation and Application Technology of Fly Ash-based Grassland Restoration; Materials Research on Preparation and Application Technology of Fly Ash-based Desert Improvement Materials. We wish to thank the editor and the reviewers for their helpful suggestions and comments that greatly improve the research.

Conflicts of Interest: The authors declare no conflict of interest. 


\section{References}

1. Wang, S.B.; Boyjoo, Y.; Choueib, A.; Zhu, Z.H. Removal of dyes from aqueous solution using fly ash and red mud. Water Res. 2005, 39, 129-138. [CrossRef] [PubMed]

2. Sun, L.Y.; Luo, K.X.; Fan, J.R.; Lu, H.L. Experimental study of extracting alumina from coal fly ash using fluidized beds at high temperature. Fuel 2017, 199, 22-27. [CrossRef]

3. Malhotra, V.M. Durability of concrete incorporating high-volume of low-calcium (ASTM Class F) fly ash. Cem. Concr. Compos. 1990, 12, 271-277. [CrossRef]

4. Li, G.; Wang, B.D.; Sun, Q.; Xu, W.Q.; Ma, Z.; Wang, H.Y.; Zhang, D.J.; Zhou, J.L. Novel synthesis of fly-ash-derived Cu-loaded SAPO-34 catalysts and their use in selective catalytic reduction of NO with NH3. Green Energy Environ. 2019, 4, 470-482. [CrossRef]

5. Teixeira, E.R.; Mateus, R.; Camoes, A.F.; Bragança, L.; Branco, F.G. Comparative environmental life-cycle analysis of concretes using biomass and coal fly ashes as partial cement replacement material. J. Clean. Prod. 2016, 112, 2221-2230. [CrossRef]

6. Ding, J.; Ma, S.K.H.; Shen, S.; Xie, Z.L.; Zheng, S.L.; Zhang, Y. Research and industrialization progress of recovering alumina from fly ash: A concise review. Waste Manag. 2017, 60, 375-387. [CrossRef]

7. Ding, J.; Yang, L.; Zheng, S.L.; Zhang, Y.; Xie, Z.L.; Shen, S.; Liu, Z.K. Study of extracting alumina from high-alumina PC fly ash by a hydro-chemical process. Hydrometallurgy 2016, 161, 58-64. [CrossRef]

8. Shaheen, S.M.; Hooda, P.S.; Tsadilas, C.D. Opportunities and challenges in the use of coal fly ash for soil improvements-A review. J. Environ. Manag. 2014, 145, 249-267. [CrossRef]

9. Song, M.; Lin, S.; Takahashi, F. Coal fly ash amendment to mitigate soil water evaporation in arid/semi-arid area: An approach using simple drying focusing on sieve size and temperature. Resour. Conserv. Recycl. 2020, 156, 104726. [CrossRef]

10. Prakash, K.; Sridharan, A. Beneficial properties of coal ashes and effective solid waste management. Prac. Period. Hazard. Toxic Radioact. Waste Manag. 2009, 13, 239-248. [CrossRef]

11. Gollakota, A.R.; Volli, V.; Shu, C.M. Progressive utilisation prospects of coal fly ash: A review. Sci. Total Environ. 2019, 672, 951-989. [CrossRef] [PubMed]

12. Lee, D.S.; Lim, S.S.; Park, H.J.; Yang, H.I.; Park, S.I.; Kwak, J.H.; Choi, W.J. Fly ash and zeolite decrease metal uptake but do not improve rice growth in paddy soils contaminated with Cu and Zn. Environ. Int. 2019, 129, 551-564. [CrossRef] [PubMed]

13. Munir, M.A.M.; Liu, G.; Yousaf, B.; Ali, M.U.; Abbas, Q.; Ullah, H. Synergistic effects of biochar and processed fly ash on bioavailability, transformation and accumulation of heavy metals by maize (Zea mays L.) in coal-mining contaminated soil. Chemosphere 2020, 240, 124845. [CrossRef]

14. Khan, I.; Umar, R. Environmental risk assessment of coal fly ash on soil and groundwater quality, Aligarh, India. Groundw Sustain. Dev. 2019, 8, 346-357. [CrossRef]

15. Singh, A.; Sarkar, A.; Agrawal, S.B. Assessing the potential impact of fly ash amendments on Indian paddy field with special emphasis on growth, yield, and grain quality of three rice cultivars. Environ. Monit. Assess. 2012, 184, 4799-4814. [CrossRef]

16. Lim, S.S.; Lee, D.S.; Kwak, J.H.; Park, H.J.; Kim, H.Y.; Choi, W.J. Fly ash and zeolite amendments increase soil nutrient retention but decrease paddy rice growth in a low fertility soil. J. Soils Sediments 2016, 16, 756-766. [CrossRef]

17. Ma, S.; Nan, H.; Wang, X.; Ding, J. The novel properties of a new inorganic water-retaining product made from coal fly ash. In Proceedings of the World of Coal Ash Conference, St. Louis, MO, USA, 13-16 May 2019.

18. Ma, S.H.; Xu, M.D.; Qi, Q.G.; Wang, X.H.; Ding, J.; Shi, J.P.; Che, L.M.G.; Zhao, Z.Q.; Zheng, S.L. A Soil Conditioner and its Preparation Method. CN108239536A, 3 July 2018.

19. Yin, P.; Shi, L. Remediation of $\mathrm{Cd}, \mathrm{Pb}$, and $\mathrm{Cu}$-contaminated agricultural soil using three modified industrial by-products. Water Air Soil Pollut. 2014, 225, 2194. [CrossRef]

20. Ahmad, M.; Usman, A.R.; Al-Faraj, A.S.; Ahmad, M.; Sallam, A.; Al-Wabel, M.I. Phosphorus-loaded biochar changes soil heavy metals availability and uptake potential of maize (Zea mays L.) plants. Chemosphere 2017, 194, 327-339. [CrossRef]

21. Chojnacka, K.; Chojnacki, A.; Górecka, H.; Górecki, H. Bioavailability of heavy metals from polluted soils to plants. Sci. Total Environ. 2005, 337, 175-182. [CrossRef] 
22. Noli, F.; Tsamos, P. Concentration of heavy metals and trace elements in soils, waters and vegetables and assessment of health risk in the vicinity of a lignite-fired power plant. Sci. Total Environ. 2016, 563-564, 377-385. [CrossRef]

23. Manivannan, A.; Ahn, Y.-K. Silicon regulates potential genes involved in major physiological processes in plants to combat stress. Front. Plant Sci. 2017, 8, 1346. [CrossRef] [PubMed]

24. Zama, E.F.; Reid, B.J.; Sun, G.X.; Yuan, H.Y.; Li, X.M.; Zhu, Y.G. Silicon (Si) biochar for the mitigation of arsenic (As) bioaccumulation in spinach (Spinacia oleracean) and improvement in the plant growth. J. Clean. Prod. 2018, 189, 386-395. [CrossRef]

C 2020 by the authors. Licensee MDPI, Basel, Switzerland. This article is an open access article distributed under the terms and conditions of the Creative Commons Attribution (CC BY) license (http://creativecommons.org/licenses/by/4.0/). 